
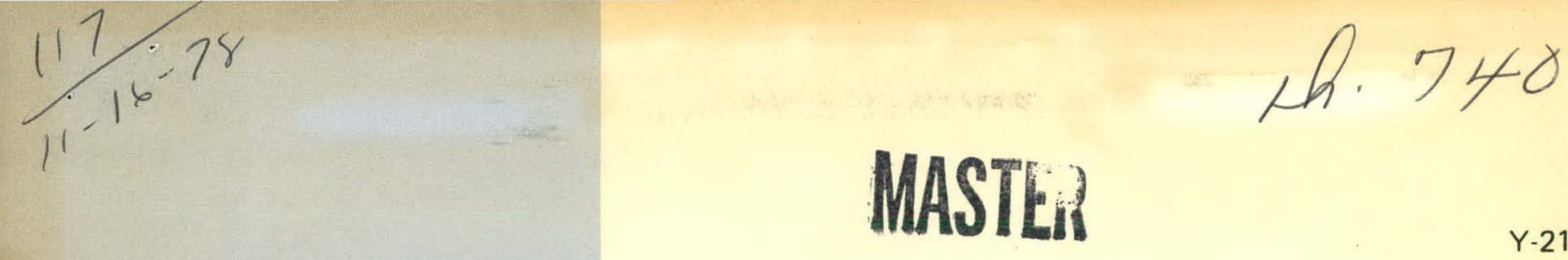

OPERATION OF A FLUIDIZED-BED DENITRIFICATION BIOREACTOR

P. A. Taylor

November 1978

UNION CARBIDE

\section{OAK RIDGE Y-12 PLANT} OAK RIDGE. TENNESSEE

prepared for the U.S. DEPARTMENT OF ENERGY under

U.S. GOVERNMENT Contract W-7405 eng 26 


\section{DISCLAIMER}

This report was prepared as an account of work sponsored by an agency of the United States Government. Neither the United States Government nor any agency Thereof, nor any of their employees, makes any warranty, express or implied, or assumes any legal liability or responsibility for the accuracy, completeness, or usefulness of any information, apparatus, product, or process disclosed, or represents that its use would not infringe privately owned rights. Reference herein to any specific commercial product, process, or service by trade name, trademark, manufacturer, or otherwise does not necessarily constitute or imply its endorsement, recommendation, or favoring by the United States Government or any agency thereof. The views and opinions of authors expressed herein do not necessarily state or reflect those of the United States Government or any agency thereof. 


\section{DISCLAIMER}

Portions of this document may be illegible in electronic image products. Images are produced from the best available original document. 
Reference to a company or product name does not imply approval or recommendation of the product by Union Carbide Corporation or the Department of Energy to the exclusion of others that may meet specifications.

Printed in the United States of America. Available from National Technical Information Service

U.S. Department of Commerce

5285 Port Royal Road, Springfield, Virginia 22161

Price: Printed Copy $\$ 4.00$; Microfiche $\$ 3.00$

This report was prepared as an account of work sponsored by an agency of the United States Government. Neither the United States Government nor any agency thereof, nor any of their employees, nor any of their contractors, subcontractors, or their employees, makes any warranty, express or implied, nor assumes any legal liability or responsibility for any third party's use or the results of such use of any information, apparatus, product or process disclosed in this report, nor represents that its use by such third party would not infringe privately owned rights. 
Date of Issue: November 15, 1978

Distribution Category: UC-69

\title{
OPERATION OF A FLUIDIZED-BED DENITRIFICATION BIOREACTOR
}

\author{
P. A: Taylor
}

Process Engineering Department

Y-12 Development Division

- NOTICE

This report was prepared as an account of work United States Govemment. Neither the

Energy States nor the United States Department of

Bnergy, nor any of their employees, nor any of their

any wors, subcontracions, of their employees, makes

a

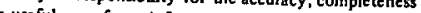

prestion, apparatus, product or

process disclosed, or represents that its use would nor

infringe privately owned rights.

\section{Oak Ridge Y-12 Plant}

P. O. Box Y, Oak. Ridge, Tẹnnessee 37830

Prepared for the Department of Energy Under US Government Contract W-7405-cng-26 


\section{ABSTRACT}

A fluidized-bed denitrification process has been developed by the Oak Ridge National Laboratory. Bacteria are allowed to grow and attach themselves to $0.25-0.60-\mathrm{mm}-\mathrm{OD}$ coal particles, and nitrate-containing solution is pumped up through the column at a velocity sufficient to fluidize the bacteria-coated coal particles. The denitrification bacteria convert the nitrate ions to nitrogen gas.

A $10-\mathrm{cm}-10$ column has been operated by Oak Ridge $Y-12$ Plant personnel to test the scale-up and operational characteristics of the fluidized bed process. The reactor consists of a tapered bottiom section for flow distribution, several straight 10-cm-ID cylindrical sections, and a tapered top section for solid/liquid disengaging.

Increasing the diameter of the reactor by a factor of two did not cause any decrease in reactor performance. The fluidized-bed reactor is characterized by short-residence-time requirements (about 2 minutes per meter of height), and by high, but variable,

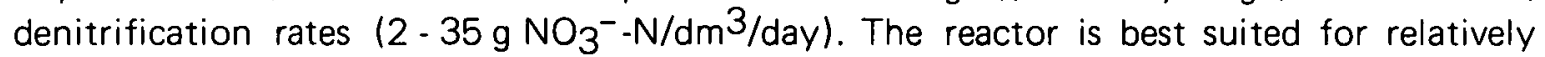
low-concentration nitrate wastes $\left(<1 \mathrm{wt} \% \mathrm{NO}_{3}^{-}\right)$. The economics of using the reactor for high-concentration wastes $\left(>20 \mathrm{wt} \% \mathrm{NO}_{3}{ }^{-}\right)$is less favorable, but still may be competitive with other reactor types. 


\section{CONTENTS}

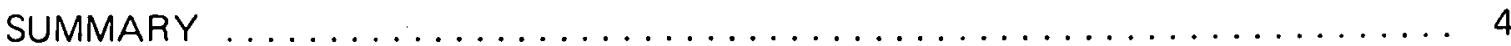

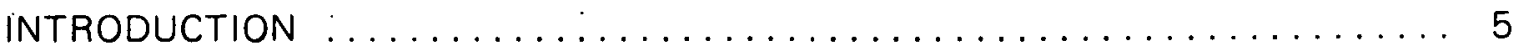

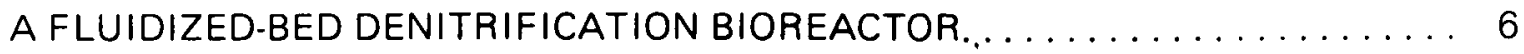

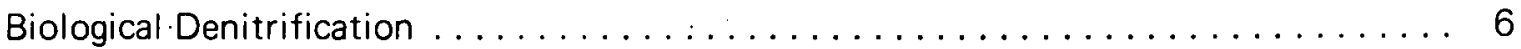

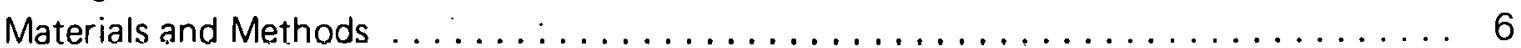

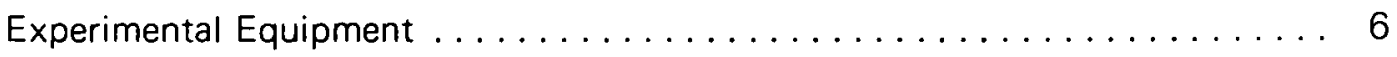

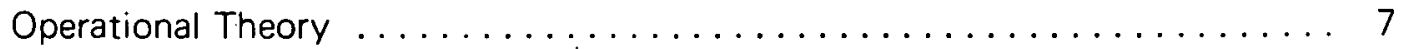

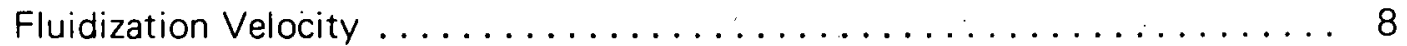

Biomass Control ................................ 8

Organic Carbon Discharge $\ldots \ldots \ldots \ldots \ldots \ldots \ldots \ldots \ldots \ldots$

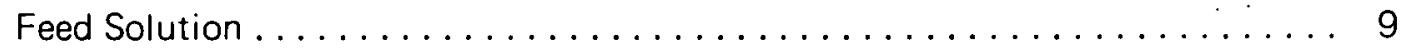

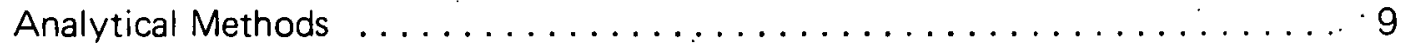

Bacteria Inoculation ............................ 10

Experimental Results ................................... 10

Rate Versus Concentration . . . . . . . . . . . . . . . . . 10

Two Columns in Series . . . . . . . . . . . . . . . . . . . . . . . . 12

Recycle-Mode Operation ... . . . . . . . . . . . . . . . . . . . . . 13

Rate Versus Temperature ... . . . . . . . . . . . . . . . . 15

Scale-up Performance . . . . . . . . . . . . . . . . . . . . 17

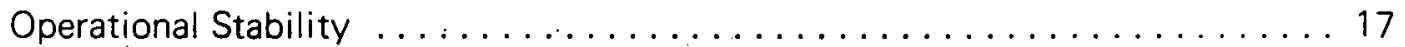

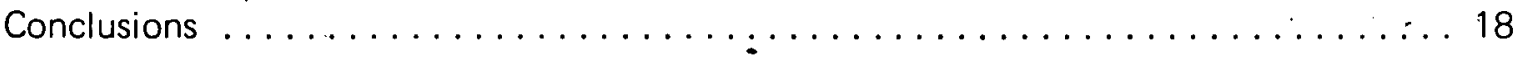

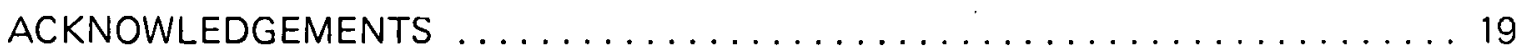

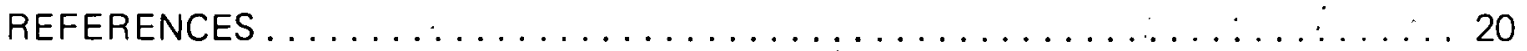




\section{SUMMARY}

A fluidized-bed process has been developed by the Oak Ridge National Laboratory and has been successfully used for biological denitrification of nitrate-containing solutions. Bacteria are allowed to grow and attach themselves to $0.25-0.60-\mathrm{mm}-\mathrm{OD}$ coal particles, and the nitrate-containing solution is pumped up through the column at a velocity sufficient to fluidize the bacteria-coated particles. A $10-\mathrm{cm}-10$ column has been operated by $\mathrm{Y}-12$ Plant personnel to test the scale-up and operational characteristics of the fluidized-bed reactor. The reactor consists of a tapered bottom section for flow distribution, several straight $10-\mathrm{cm}-1 \mathrm{D}$ cylindrical sections, and a tapered top section for solid/liquid disengaging.

Operating performance of the 10-cm-ID column compares well with data from a $5-\mathrm{cm}-1 \mathrm{D}$ column that was operated by ORNL personnel. The operating performance should not be affected by scale up to larger diameters as long as adequate flow distribution can be maintained.

. The fluidized-bed reactor is characterized by short-residence-time requirements (about 2 minutes per meter of height). The denitrification rates were high, but variable (2 $-35 \mathrm{~g} \mathrm{NO}_{3}-\mathrm{N} / \mathrm{dm}^{3} /$ day), depending on the nitrate concentration, trace nutrient concentration, and other unknown factors.

Operational stability of the reactor has been somewhat of a problem. An adequate biomass control procedure is required for long-term operation. Biomass control in the $10-\mathrm{cm}-1 \mathrm{D}$ reactor was successfully provided by a vibrating screen arrangement; however, unexplained fluctuations in the denitrification performance of the reactor were still noted. Large-scale reactor design must accommodate these fluctuations by sizing the reactor to produce a dischargeable effluent even on the worst operating days.

The fluidized-bed reactor is best suited for relatively low-concentration nitrate wastes $\left(<1 \mathrm{wt} \% \mathrm{NO}_{3}^{-}\right.$), where little or no dilution will be required. Higher-concentration wastes can be processed by appropriate dilution, but the competitive advantage of this type of reactor, compared to a stirred bed, tends to decrease as the nitrate concentration of the waste stream increases. Even for extremely concentrated nitrate wastes, the size of the reactor required to treat the waste stream should be smaller when using a fluidized-bed reactor than when using a stirred-bed reactor. However, the increased labor time required for the operation of the fluidized bed may outweigh the advantages of the size reduction. 


\section{INTRODUCTION}

Nitrate-containing waste water is commonly found within the nuclear-fuel-cycle industries as well as 'in many other industries such as fertilizer and synthetic fiber plants. Biological denitrification has proven to be an economical method for treating low-concentration nitrate wastes; however, its use with concentrated industrial wastes has been quite limited. Denitrification is defined as the biological reduction of nitrate ions to nitrogen gas. ${ }^{1}$ The chemistry involved in this process will be described in the body of this report.

The Oak Ridge National Laboratory has a contract with the Department of Energy $(D O E)^{(a)}$ to develop treatment methods for the waste streams generated in the nuclear fuel cycle. A major part of this work is the development of a fluidized-bed reactor for the biological denitrification of nitrate-containing waste water. The Oak Ridge Y-12 Plant $(b)$ has studied the scale-up and operational characteristics of this type of reactor, and this report is a summary of the work that was performed for the Oak Ridge National Laboratory. (b)

(a) Contract 3370-1389 (DOE-AG02-02-32-0).

(b) Operated by the Union Carbide Corporation's Nuclear Division for the Department of Energy. 


\section{A FLUIDIZED-BED DENITRIFICATION BIOREACTOR}

\section{BIOLOGICAL DENITRIFICATION}

Biological denitrification is defined as the dissimilatory reduction of nitrates or nitrites to nitrogen gas. A wide variety of bacteria are capable of denitrification, including various species from the genera Pseudomonas, Micrococcus, and Bacillus. ${ }^{1}$ In this process, nitrate $\left(\mathrm{NO}_{3}{ }^{-}\right)$or nitrite $\left(\mathrm{NO}_{2}{ }^{-}\right)$ions replace oxygen as the terminal electron acceptor of the respiratory process. The products of the denitrification form of metabolism are nitrogen, carbon dioxide, and water. These bacteria are facultative in that they are capable of using either oxygen or nitrate as the terminal electron acceptor. Since aerobic respiration releases more energy than denitrification, oxygen will be used preferentially. In order for denitrification to occur, the supply of oxygen must be limited.

An organic carbon source (such as sugars, organic acids, or alcohols) is required for denitrification, along with various trace nutrients such as phosphate, magnesium, and sulfate. Environmental conditions needed for optimum growth typically include a $\mathrm{pH}$ of $7.0-8.5$ and a temperature of $20 \cdot 40^{\circ} \mathrm{C}$.

Using ethanol as the organic carbon source, the denitrification reaction is believed to be:

$$
\begin{aligned}
& \mathrm{NO}_{3}^{-}+0.48 \mathrm{C}_{2} \mathrm{H}_{5} \mathrm{OH} \rightarrow 0.04 \mathrm{C}_{5} \mathrm{H}_{7} \mathrm{NO}_{2}+0.48 \mathrm{~N}_{2}+0.08 \mathrm{CO}_{2}+\mathrm{OH}^{-}+0.8 \mathrm{H}_{2} \mathrm{O} \text {. } \\
& \text { (biomass) }
\end{aligned}
$$

The coefficient on the biomass production can vary, depending on the conditions in the reactor and the stage of growth of the bacteria.

\section{MATERIALS AND METHODS}

\section{Experimental Equipment}

The 10-cm-ID bioreactor was constructed from Pyrex glass sections, and consists of a tapered bottom, five cylinders with sample ports at the junctions, a top disengaging tapered section, and a liquid/gas separating section. The column was originally built with five cylindrical sections, but two additional cylinders were added later. A second bioreactor was also built, similar in design to the first, with seven cylindrical sections (see Figure 1 ).

A general description of each section is as follows (refer to Figure 1): A. A tapered bottom section, enlarged from 0.5 to $10 \mathrm{~cm}$ ID over a $15-\mathrm{cm}$ length, for flow
distribution.

B. A 2-cm-high Plexiglas sampler.

C. A 60-cm-long straight cylindrical section (seven sections total). 
D. A solids-disengaging section, 60-cm-long, with a 10 to $15-\mathrm{cm}$ ID taper.

E. A liquid/gas disengaging section, $15 \mathrm{~cm}$ ID by $60 \mathrm{~cm}$ long.

\section{Operational Theory}

Denitrification bacteria are allowed to grow and attach themselves to some solid support medium such ds sañd, coal, or alumino (0.25 - 0.60-mm-ID coal particles were used in these experiments). The bacteria-coated particles form a stable, biologically active bed. Nitrate-containing waste water is pumped up through the column at a rate sufficient to fluidize the bacteria-coated coal particles.

The solid particles keep the bacteria from being washed out of the reactor, even at very shiurt fluid residence times ( $\sim 2$ minutes per meter of column height). The movement of the particles caused by the fluidization allows the nitrogen gas, formed by the bacteria, to escape, and also keeps the particles from sticking together and plugging the reactor. Both gas-locking and plugging problems are common in packed-bed reactors that are used for high-strength nitrate wastes.

Nitrate inns hecome toxic to the bacteria at levels above $10,000 \mathrm{mg} \mathrm{NO}_{3}^{-} / \mathrm{dm}^{3}$; therefore, the concentration of the solution entering the column must be kept below this level. Also, the length of column required to reduce the nitrate concentration to dischargeable levels increases as the nitrate concentration increases. For these reasons it is preferable to keep the entering nitrate concentration fairly low $14000 \mathrm{mg} \mathrm{NO}_{3}-/ \mathrm{dm}^{3}$ would be a reasonable maximum).

If the riitrate concentration of a given waste stream is too high, it will be necessary to dilute the stream before it enters the reactor.

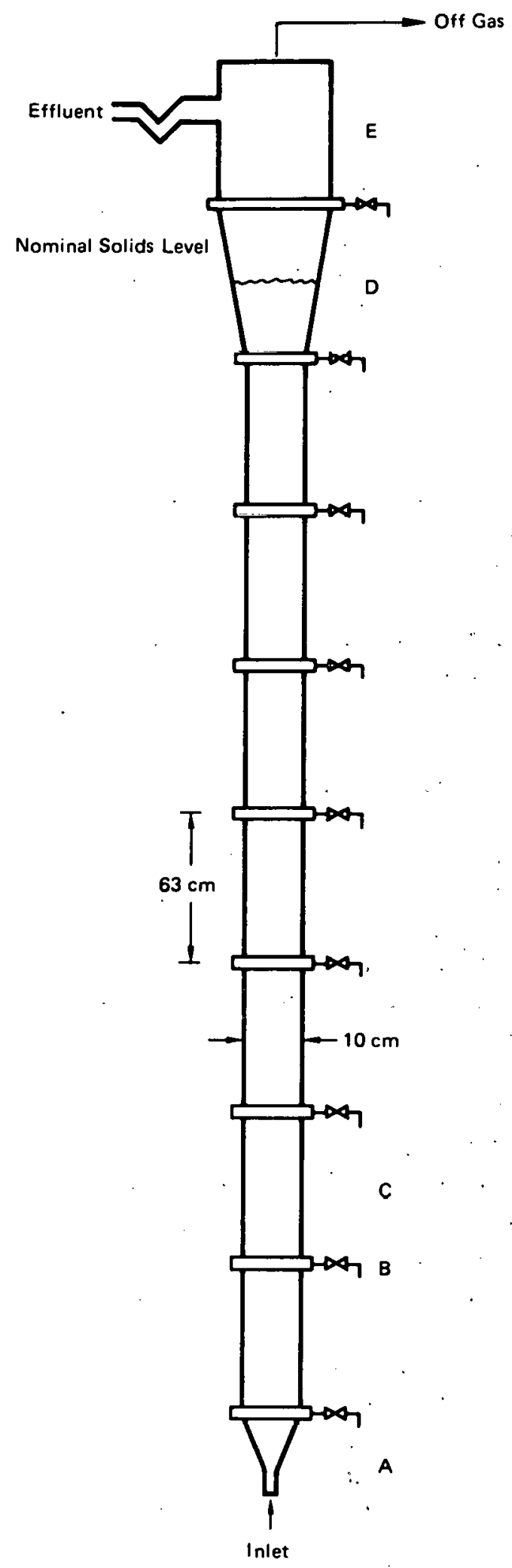

Figure 1. BIOREACTOR WITH A $10-\mathrm{cm}-10$ COLUMN. 
Normally, fresh water would be used for this purpose, but it is possible to use a portion of the effluent stream from the bioreactor in some cases. This procedure is described in the section on Recycle-Mode Operation. (Page 13)

\section{Fluidization Velocity}

The liquid flow rate required to fluidize the support medium is dependent on the size and density of the particles plus other design factors. For the $0.25-0.60-\mathrm{mm}-1 \mathrm{D}$ coal particles used in the experiments, a fluidization velocity of $51 \mathrm{~cm} / \mathrm{min}$ provided a $100 \%$ bed expansion. This velocity corresponds to a flow rate of $4 \mathrm{dm} 3 / \mathrm{min}(\mathrm{c})$ for the $10-\mathrm{cm}-1 \mathrm{D}$ column. The tapered/iquid/solid disengaging section at the top of the column allows more flexibility in flow rates. A given change in flow rate will cause a smaller change in the height of the solids interface in the tapered section than it would in a straight liquid/solid separator. This relationship means that there is a wider range of flow rates between initial fluidization and solids washout for a column with a tapered rather than straight disengaging section.

During operation of the column, the position of the solid/liquid interface would vary somewhat, but it was normally kept about halfway into the top tapered section. A solids inventory of 16 liters of coal particles (measured dry) was maintained in the column.

\section{Biomass Control}

During operation of the column, the thickness of the bacteria layer on the coal particles slowly increases. The resultant increase in particle size causes a decrease in the surface-to-volume ratio of the particles which, in turn, causes a net reduction in the biological activity of the column. Also, nitrogen gas formed by the inner bacteria on the coal particle can be trapped under top layers of bacteria, causing the particle to float. These potential problems can be avoided by periodically removing the excess biomass.

Several methods have been used to remove the excess biomass. The first method was to remove a portion of the bed each day, wash it by hand, and return the cleaned coal to the column. This method works quite well on a small scale, but would be impractical for a large reactor. Shearing-type cleaning, such as running the coated particles through a centrifugal pump, will remove the excess biomass, but there is a tendency for a sticky film to build up on the coal particles.

The cleaning method used for most of the experiments in the $10-\mathrm{cm}-1 \mathrm{D}$ column was a vibrating screen with a recirculating water spray. This method was used in a continuous mode and has worked satisfactorily. The heavily coated particles are less dense than the clean coal particles, so they tend to rise to the top of the column. A side stream of liquid and particles is continuously removed from the top portion of the column and transferred

(c) $1 \mathrm{dm}^{3}=1$ liter. 
to the vibrating screen. The washed coal particles are then pumped back to the top of the column. The clean coal is more dense and will tend to migrate to the bottom of the column.

\section{Organic Carbon Discharge}

Several forms of organic carbon are discharged from the denitrification reactors: excess feed carbon, biomass, and soluble organics produced by the bacteria in the reactor. In some cases, the combination of organic carbon sources may exceed the permissible biological oxygen demand (BOD) discharge level. For satisfactory operation it is necessary to have a slight excess of the organic carbon feed leaving the column to take care of variations in the amount of nitrate entering the reactor. Excess biomass and soluble organics produced by the bacteria are an unavoidable feature of biological denitrification. The types of organic carbon that leave the reactor should be amenable to treatment by standard sanitary sewage procedures; however, this assumption has not been demonstrated yet.

\section{Feed Solution}

The feed solution used for the tests reported here was an ammonium nitrate solution with ethanol added as the organic carbon source. Ammonium ions are nontoxic even at relatively high concentrations, and do not form any solid precipitates that could interfere with the operation of the column. Ethanol was used as the carbon source because it could be accurately measured even in the presence of other organics, as described in the next section (Analytical Methods). The recipe for a $6000-\mathrm{mg} \mathrm{NO}_{3}-/ \mathrm{dm}^{3}$ feed solution is given in Table 1. : The $6000-\mathrm{mg} \mathrm{NO} \mathrm{NO}^{-} / \mathrm{dm}^{3}$ feed solution was mixed with dilution water just before entering the column to produce the desired inlet concentration.

During the recycle and two-columns-inseries tests, the phosphate nutrient was removed from the feed solution and added directly to the bottom of the column with a small metering pump at a rate sufficient to maintain a level of $2 \mathrm{mg} \mathrm{PO}_{4}-3 / \mathrm{dm}^{3}$ in the stream entering the column. Using this procedure it was possible to maintain this higher phosphate concentration in the reactor without the danger of forming insoluble phosphate complexes in the feed solution.

\section{Analytical Methods}

The chemical analyses were made by the technician who was operating the column.

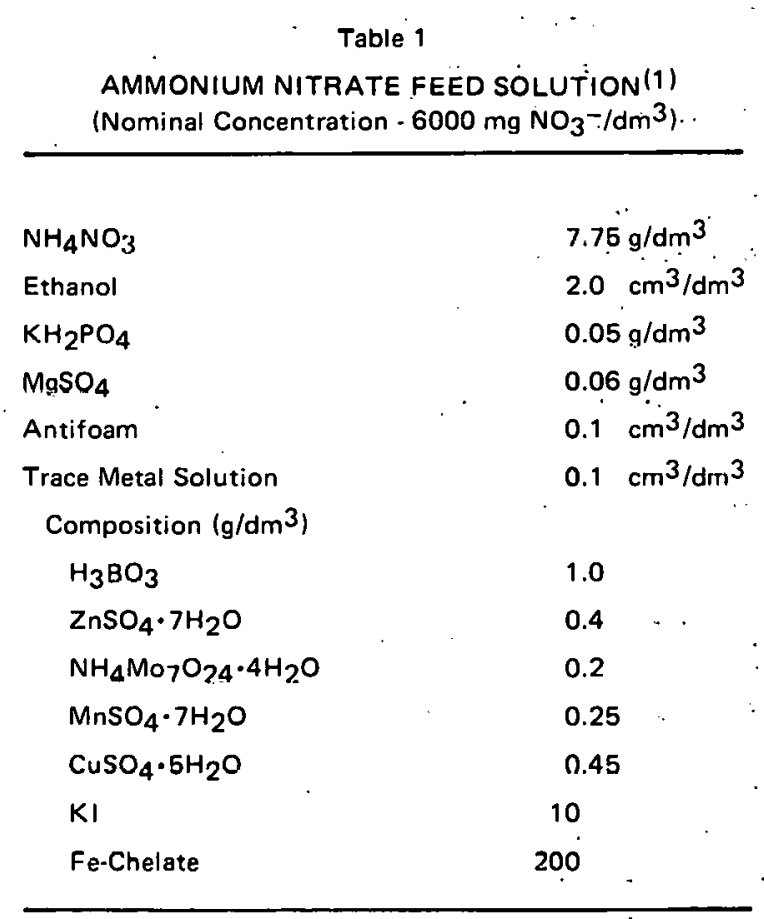

(1) Flow rate to the column is dependent on the inlet concentration desired. A feed rate of $170 \mathrm{~cm}^{3} / \mathrm{min}$ will give an inlet concentration of $250 \mathrm{mg} \mathrm{NO}_{3}-/ \mathrm{dm}^{3}$. 
The measurements for nitrate, nitrite, and ethanol were performed by using standard spectrophotometric techniques. 2 Nitrate was measured by direct ultraviolet absorption at a wavelength of $220 \mathrm{~nm}(2200 \AA) .2$ A correction for dissolved organics was occasionally made by subtracting two times the reading at $275 \mathrm{~nm}$ from the reading at $220 \mathrm{~nm}$. However, this correction factor was normally found to be insignificant in these samples.

Nitrite samples were combined with sulfanilic acid, EDTA, and napthylamine hydrochloride to produce a red azo dye. 2 . The intensity of the dye, which is directly proportional to the nitrite concentration, was measured by absorbance at $520 \mathrm{~nm}$.

Ethanol was measured by using a commercial blood analysis kit from Calbiochem. (d) In this method, ethanol is enzymatically oxidized to acetaldehyde by nicotinamide-adenine dinucleotide (NAD). A stoichiometric amount of the reduced form of nicotinamide-adenine dinucleotide (NADH) is formed in this reaction. The concentration of NADH was measured by absorbance at $340 \mathrm{~nm}$.

The concentration of total organic carbon (TOC) in the reactor solution was measured with an automatic carbon analyzer. The volume of offgas was measured with a wet-test meter, and the composition was measured periodically, using a gas chromatograph.

\section{Bacteria Inoculation}

The bacteria culture that was used to seed the early fluidized bed reactors was from a stock of frozen bacteria that had been prepared for starting the denitrification reactors which are in operation at the $\mathrm{Y}-12$ Plant: Subsequent reactors were seeded with bacteria from the previous reactors.

The original frozen bacteria seed was a mixed culture containing six major species of denitrification bacteria including species from the genera Pseudomonas, Paracoccus, Citrobacter, and Alcaligenes. (e)

The various columns that have been operated were all open to contamination by other bacteria, so the bacteria population has probably changed considerably. Bacteria-coated coal particles from a $5-\mathrm{cm}-1 \mathrm{D}$ column that was operated by ORNL personnel were used to seed the $10-\mathrm{cm}-I D$ column.

\section{EXPERIMENTAL RESULTS}

\section{Rate versus Concentration}

Effect of nitrate concentration on the denitrification rate has been measured by using various inlet concentrations. The column for these tests had five, straight, $10-\mathrm{cm}$-ID sections

(d) US Patent 3,926,736.

(e) Bacteria identification supplied by G. W. Claus of Virginia Polytechnical Institute and State University. 
with a total active length of 3.2 meters. The nitrate and nitrite concentrations were measured along the length of the column. The concentration of combined nitrogen (nitrate + nitrite) was used for all of the calculations.

When the denitrification rate is based on the amount of bacteria in the reactor $\left(\mathrm{g} \mathrm{NO}_{3}^{-}-\mathrm{N}\right.$ reduced/g bacteria/day)., zero-order kinetics are expected for nitrate concentrations above $5 \mathrm{mg} \mathrm{NO}_{3}-/ \mathrm{dm}^{3}$ (ie, nitrate concentration has no effect on the denitrification rate). 1,3,4

However, increasing the nitrate concentration in the reactor does cause an increase in the equilibrium bacteria concentration. Having a larger bacteria population in the reactor causes an increase in the denitrification rate when the rate is based on the volume of the reactor (g NO $3^{-}-\mathrm{N}$ reduced/dm $3 /$ day). The volume-based rates, which are used in this report, should show first-order-type kinetics (ie, increasing the nitrate concentration will increase the denitrification rate).

For these tests, three different inlet nitrate concentrations were used $(1000,350$, and $250 \mathrm{mg} \mathrm{NO} 3^{-} / \mathrm{dm}^{3}$ ). In each test, the inlet concentration, temperature, and total flow rate were kept relatively constant over an extended period of time. The nitrate and nitrite concentrations were measured at each sample port on the column once each day, and the combined nitrogen concentration $\left(\mathrm{NO}_{3}^{-}+\mathrm{NO}_{2}^{-}\right)$was calculated for each. A typical nitrogen profile in the column is indicated in Figure 2 for each inlet concentration. For each test, the raw data showed a large amount of scatter (ie, the performance of the column varied from day to day). This problem is discussed in the section on Operational Stability. (Page 17)

For each section of the column, the average combined nitrogen concentration

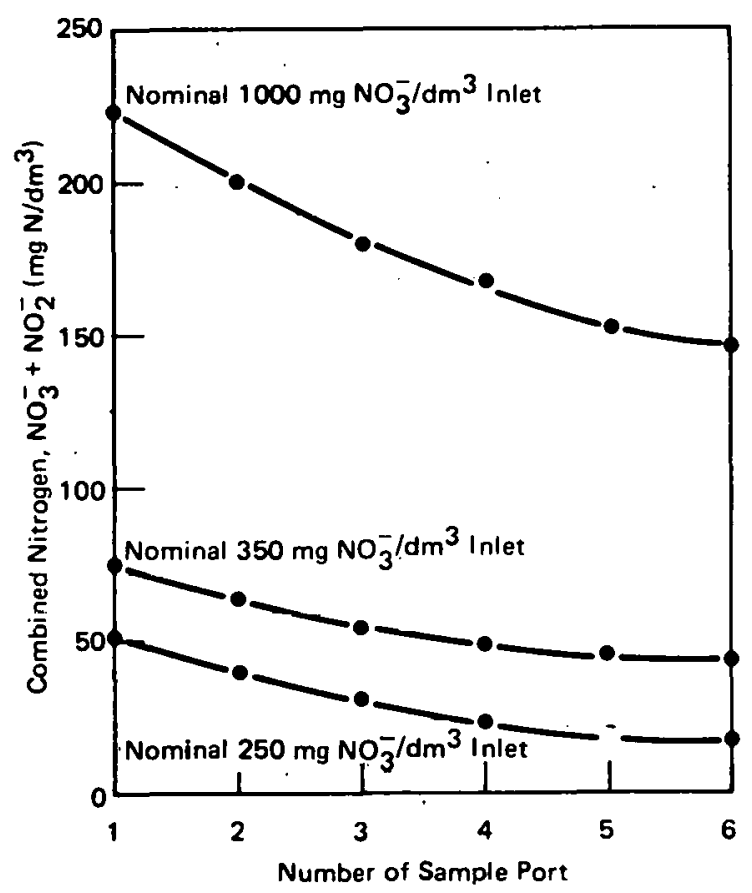

Figure 2. NITROGEN PROFILE IN THE REACTOR COLUMN FOR VARIOUS INLET CONCENTRATIONS. and the denitrification rate were calculated. The denitrification rates were calculated, based on the empty volume of the... column.

Figure 3 reports the results of the rate-versus-nitrogen concentration calculations. These curves show the expected first-order relationship between rate and nitrogen concentration. However, the fact that the results from the three tests do not fall on the same line indicates that the rate is not determined by the nitrogen concentration alone. 'The dotted line connecting the initial denitrification rate for each inlet 


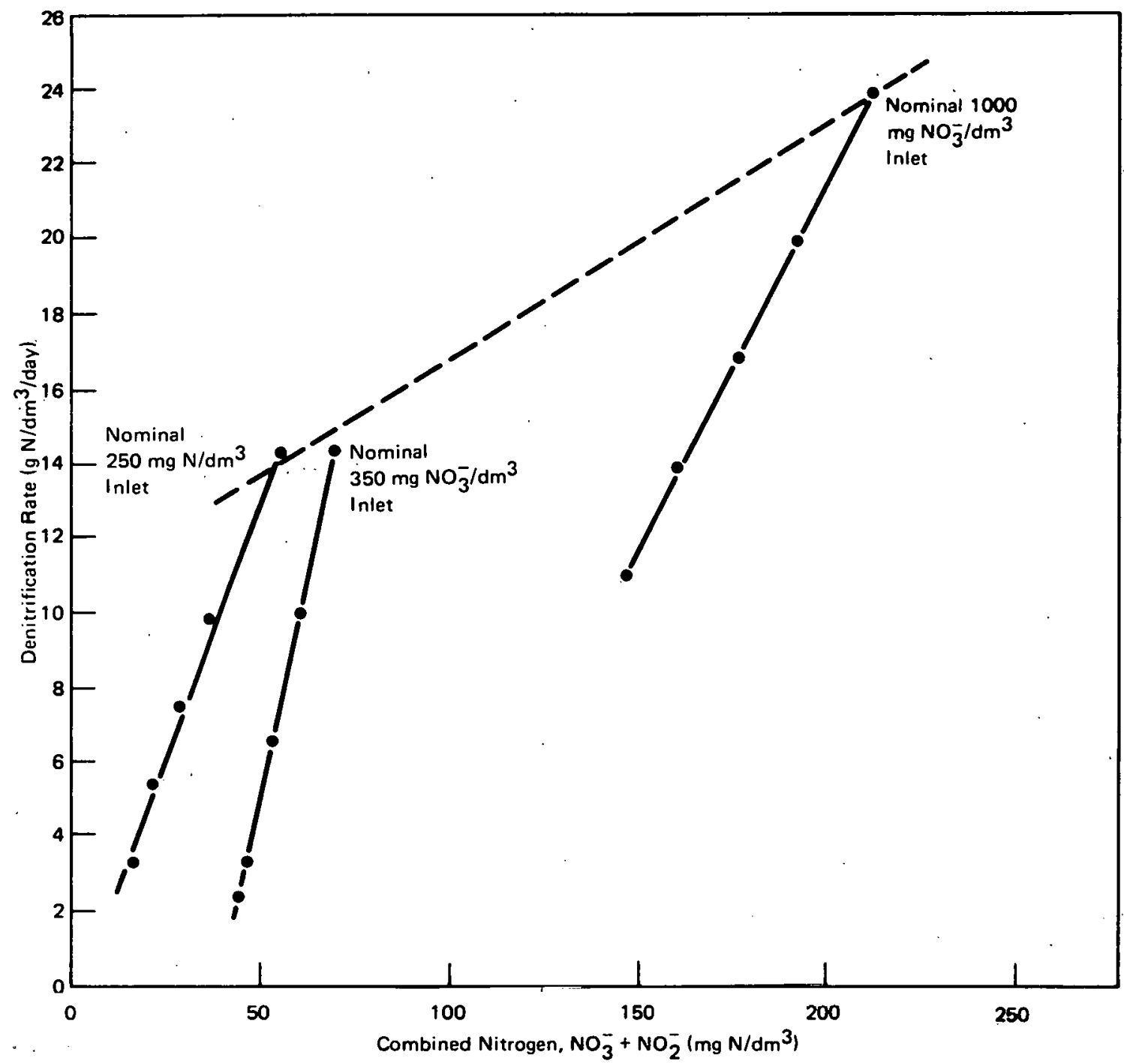

Figure 3. RATE VERSUS CONCENTRATION FOR VARIOUS INLET CONCENTRATIONS. (Rates were Calculated from Nitrogen Concentration-Versus-Column Height Data Shown in Flgure 2; Rate $=$ Change in Nitrogen Concentratlon/Corresponding Fluid Residence Timel

concentration shows the type of result that would be expected if nitrogen concentration alone controlled the rate.

The rapid drop in the denitrification rate along the length of the column for each test indicates that either an essential nutrient is being used up or that an inhibitory substance is being produced in the reaction. The results in the two-column-in-series section help clarify the cause of the rapid drop in rates.

\section{Two Columns in Series}

The rapid drop in the denitrification rate along the length of the column that was observed in the previous experiments suggested that further work was needed. A longer column was 
needèd to determine if reasonable rates could be maintained toward the end of a long column. The active length of the column was increased to 4.4 meters by adding two more cylindrical sections, and a second column was also built similar to the new first column. The effluent from the first column was run into a surge drum and then pumped into the bottom of the second column, giving a total active length of 8.8 meters.

An important change in the operating procedure was made before this test. The phosphate nutrient was removed from the feed solution and added directly to the bottom of the column by using a small metering pump. This change allowed the phosphate concentration in the column to be increased without the danger of forming metal phosphate precipitates in the feed drum. An inlet phosphate concentration of $2 \mathrm{mg} \mathrm{PO}_{4}-3 / \mathrm{dm}^{3}$ was maintained.

An inlet concentration of $1000 \mathrm{mg}$ $\mathrm{NO}_{3}-/ \mathrm{dm}^{3}$ was used in this test. The nitrogen profile along both columns is seen in Figure 4. The average nitrogen concentration and denitrification rate were calculated for each section of the columns, and these results are reported in Figure 5. Results from the single-column tests are shown for comparison. It can be seen that the denitrification rate started out higher and did not drop as fast as in the previous tests. These results suggest that a lack of phosphate was depressing the biomass activity and causing the rapid drop in the denitrification rates that was observed previously. As in the previous tests, wide day-to-day variations in column performance were noted.

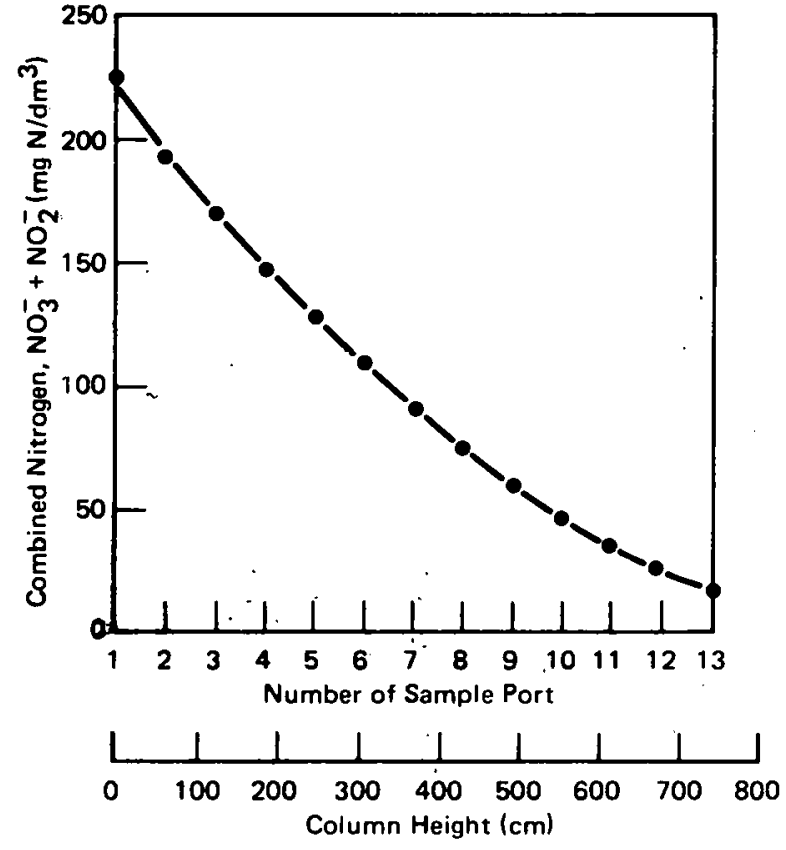

Figure 4. NITROGEN PROFILE IN THE DUAL COLUMN. (Nominal $1000 \mathrm{mg} \mathrm{NO}_{3}-/ \mathrm{dm}^{3}$ Inlet)

\section{Recycle-Mode Operation}

In the single-pass mode of operation, a large amount of water is required for dilution if concentrated waste streams are to be processed. If the cost or quantity of dilution water is the limiting factor, it can be minimized by using a portion of the treated effluent, which has a near-zero nitrate concentration, to dilute the concentrated feed solution.

In this mode of operation, any impurities present in the feed solution will build up in the column to a concentration dictated by the proportion of effluent recycled. Care must be taken to prevent any impurity from building up to a toxic level. Fresh water can be added to the solution entering the column to dilute the impurities to nontoxic levels. The carbon-to-nitrogen ratio must also be monitored closely since any unusual organic carbon and metabolic products are returned to the bottom of the column which can cause the 
concentration to increase to toxic levels. (The concentration that will cause toxic results depends on the type of organic carbon used and on other factors.)

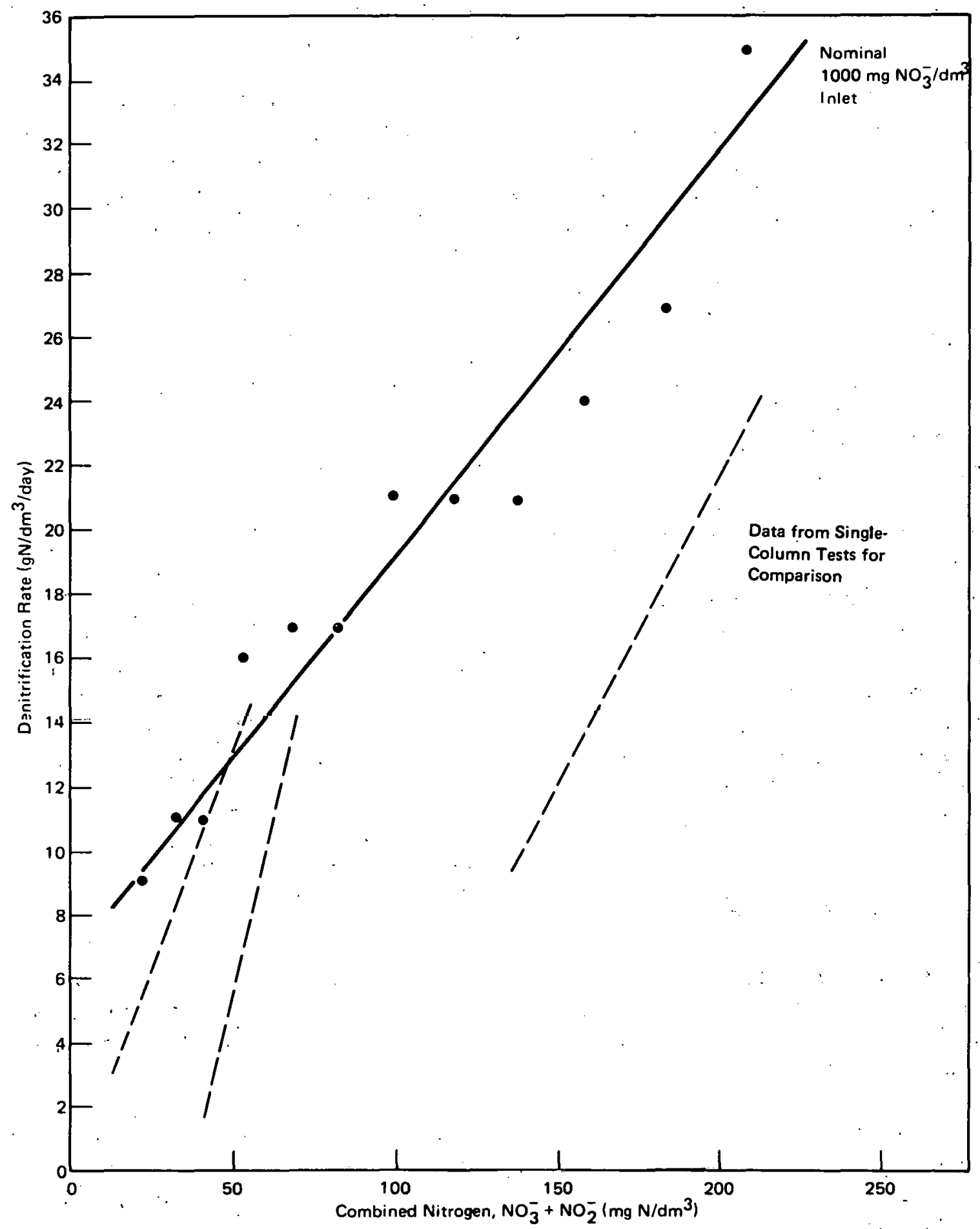

Figure 5. RATE VERSUS CONCENTRATION FOR TWO COLUMNS IN THE SERIES TESTS. (Data Points Represent Denitrification Rate and Average Nitrogen Concentration for Each $63-\mathrm{cm}$ Section of the Column) 
The 10-cm-ID bioreactor has been operated with a 9:1 ratio of recycle water to feed at an inlet concentration of $200 \mathrm{mg} \mathrm{NO} 3^{-} / \mathrm{dm}^{3}$. Effluent solution was pumped to the bottom of the column at a rate of $3600 \mathrm{~cm} 3 / \mathrm{min}$ where it was combined with $400 \mathrm{~cm} 3 / \mathrm{min}$ of fresh feed before entering the column. A typical nitrate profile for the column is given in Figure 6. The denitrification rate and the average nitrate concentration were calculated for each $63-\mathrm{cm}$ section of the column. This information is contained in Figure 7. The overall denitrification rate was $6.1 \mathrm{~g} \mathrm{NO}_{3}^{-}-\mathrm{N} / \mathrm{dm}^{3} /$ day. A 99:1 recycle ratio was also tried for a short while, but this ratio appeared to be too high, even for chemically prepared feed solutions.

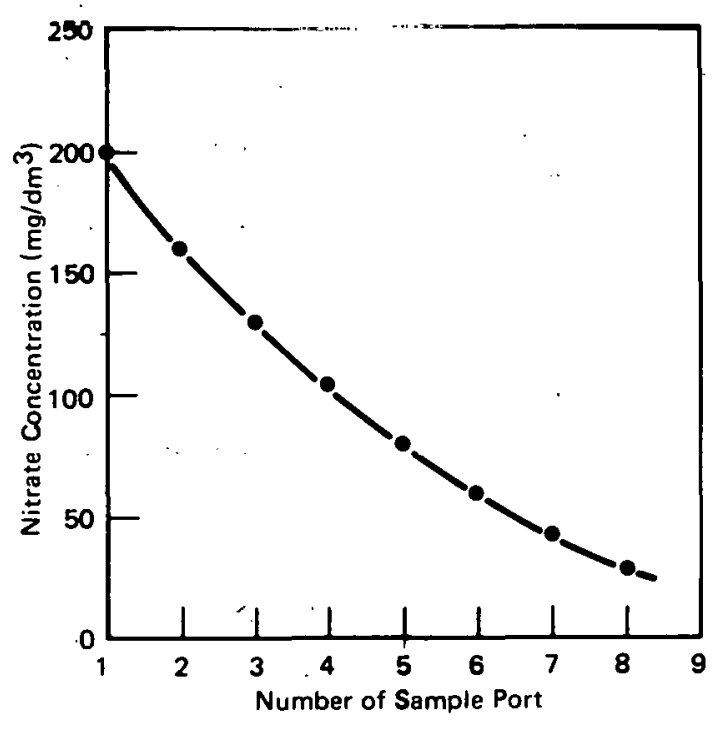

Figure 6. NITRATE CONCENTRATION AS A FUNCTION OF THE COLUMN HEIGHT FOR RECYCLEMODE OPERATION. (Adapted from ORNL Drawing 78-5105)

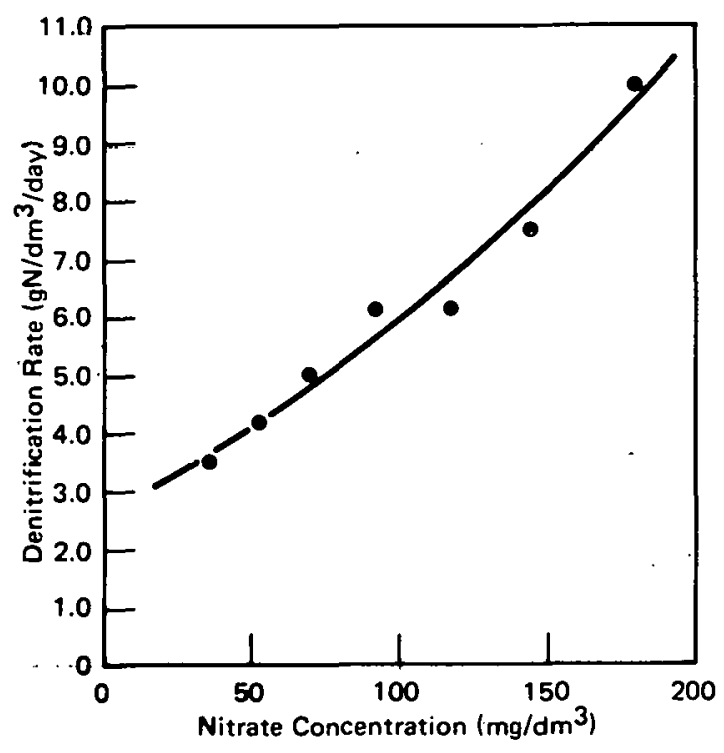

Figure 7. DENITRIFICATION RATE AS A FUNCTION OF THE CONCENTRATION FOR RECYCLE-MODE OPERATION. (Adapted from ORNL Drawing 78-5106)

In some situations, the extra care required for the recycle mode of operation will be more than compensated for by the reduction in the dilution water requirements.

\section{Rate versus Temperature}

Effect of temperature on the denitrification rate has been measured in the $10-\mathrm{cm}-10$ column. The first set of experiments used a heat exchanger to control the inlet temperature to the column. The maximum temperature achievable with this design was $22^{\circ} \mathrm{C}$. The inlet concentration was kept at $1000 \mathrm{mg} \mathrm{NO}_{3}-/ \mathrm{dm}^{3}$ for this set of experiments. At the lower inlet temperatures, the combination of heat generated by the bacteria and convective heat flow, into the column caused an increase in temperature along the length of the column. To minimize the effect of these temperature changes, the denitrification rate in the first $63-\mathrm{cm}$ section of the column was used for comparing the rates at the various temperatures. Figure 8 reports the results of these experiments. It can be seen that increasing the temperature has a dramatic effect on the denltrification rate. 
A second set of rate-versus-temperature experiments was performed three months later. A direct steam-injection system was installed to control the inlet temperature. The denitrification rate was measured at 22,27 , and $32^{\circ} \mathrm{C}$. The inlet concentration for these tests was $500 \mathrm{mg} \mathrm{NO} \mathrm{NO}_{3} / \mathrm{dm}^{3}$. At these temperatures, the heat generated by the bacteria was about balanced by the convective heat loss from the column. Since the temperature remained reasonably constant through the column in these tests, the overall denitrification rate was calculated. No increase in rate was observed when the temperature was increased from 27 to $32^{\circ} \mathrm{C}$. Results from all of these experiments are shown in Figure 9. The rates are plotted as a

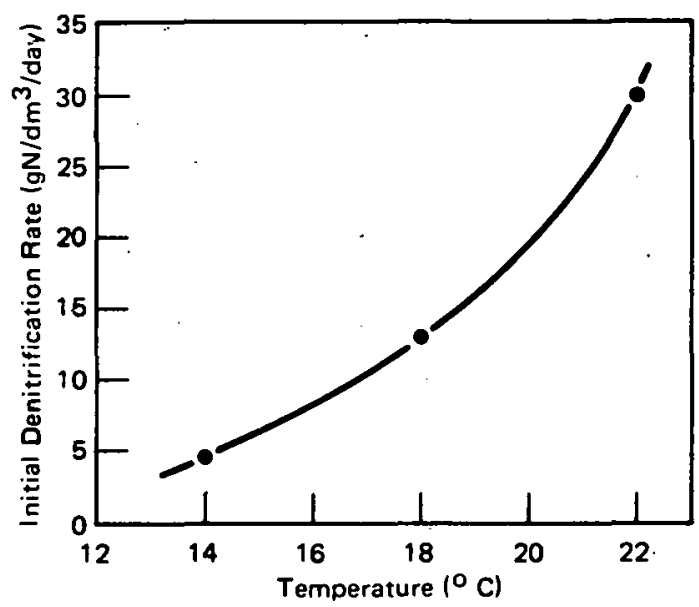

Figure 8. DENITRIFICATION RATE AS A FUNC. TION OF TEMPERATURE FOR THE $1000 \mathrm{mg} \mathrm{NO}_{3}-/ \mathrm{dm}^{3}$ INLET CONCENTRATION. (Adapted from ORNL Drawing 78-5090)

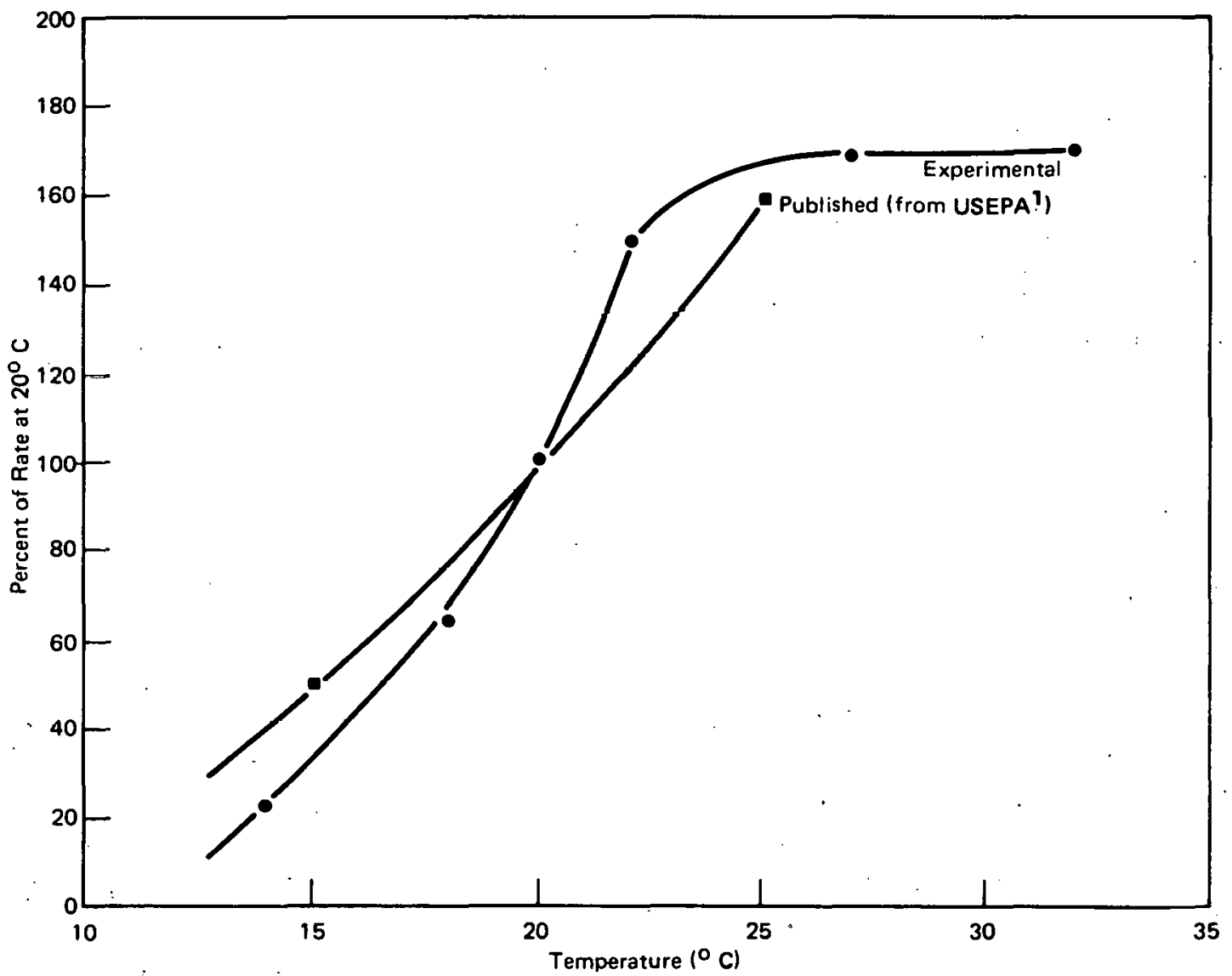

Figure 9. RATE-VERSUS-TEMPERATURE CURVES FROM PUBLISHED DATA AND DATA OBTÄINED FROM THE SECOND SET OF EXPERIMENTS. (Adapted from ORNL Drawing 78-5089) 
percentage of the rate at $20^{\circ} \mathrm{C}$ in order to remove the effects of the different nitrate concentrations in the two sets of experiments. A compilation of other published results is included in Figure 9 for comparison. ${ }^{1}$

\section{Scale-Up Performance}

Design of the $10-\mathrm{cm}-1 \mathrm{D}$ column was based on a $5-\mathrm{cm}-1 \mathrm{D}$ column that had been operated previously by ORNL personnel. The columns were the same height; but the liquid throughput of the $10-\mathrm{cm}-1 \mathrm{D}$ column was four times greater. For each set of operating conditions, the performance of the two columns was ahnut identical.

The performance of a larger column should be fairly independent of the diameter as long as adequate flow distribution is maintained. Presence of the bacteria-coated coal particles in the column helps to maintain proper flow distribution.

\section{Operational Stability}

During experimental operation of the $10-\mathrm{cm}-1 \mathrm{D}$ column it was permissible to discharge nitrate wastes at fairly high concentrations since the total flow rate was relatively low. However, full-scale columns will be required to meet specific discharge levels. The exact nitrate concentration that can be discarded will vary, depending on the location of the plant. In the State of Tennessee, some discharges will be restricted to a maximum of $45 \mathrm{mg}$ $\mathrm{NO}_{3}{ }^{-} / \mathrm{dm}^{3}$. Thus, the operational stability of a full-scale column will be very important.

During the rate-versus-concentration expcriments, performance of the column varied considerably from day to day. Thus, the outlet nitrate conncentration was not constant for a given inlet concentration. The range of variation is seen from the data in Table 2.

A full-scale system must be designed so that an acceptable effluent is obtained even on the worst operating day. This restriction means that the column must be longer than would be required to obtain an acceptable effluent on most days. Using the dual column ( 8.8 meters of active length) at an inlet concentration of $1000 \mathrm{mg} \mathrm{NO} 3^{-} / \mathrm{dm}^{3}$, the effluent concentration was $300 \mathrm{mg} \mathrm{NO} 3^{-} / \mathrm{dm}^{3}$ on the worst operating day. This result would suggest that an 8.8-meter column could accept a $700-\mathrm{mg} \mathrm{NO} 3^{-} / \mathrm{dm}^{3}$ inlet concentration and routinely produce an effluent stream with a nitrate concentration below $45 \mathrm{mg} / \mathrm{dm}^{3}$.
Table 2

OPERATING PERFORMANCE FROM RATE-VERSUSCONCENTRATION TESTS

\begin{tabular}{cccc}
\hline $\begin{array}{c}\text { Active } \\
\begin{array}{c}\text { Column } \\
\text { Height } \\
(\mathrm{m})\end{array}\end{array}$ & $\begin{array}{c}\text { Inlet } \\
\text { Concentration } \\
\left(\mathrm{mg} \mathrm{NO}_{3}-/ \mathrm{dm}^{3}\right)\end{array}$ & \multicolumn{2}{c}{$\begin{array}{c}\text { Outlet } \\
\text { Concentration } \\
\left(\mathrm{mg} \mathrm{NO}_{3}-/ \mathrm{dm}^{3}\right)\end{array}$} \\
\cline { 3 - 4 } & Average & Range \\
\hline 3.2 & 1000 & 645 & $530-930$ \\
3.2 & 350 & 200 & $130-245$ \\
3.2 & 250 & 70 & $50-80$ \\
8.8 & 1000 & 80 & $20-300$ \\
\hline
\end{tabular}

(1) A combination of $\mathrm{NO}_{3}^{-}$and $\mathrm{NO}_{2}^{-}$. 


\section{CONCLUSIONS}

A fluidized-bed process has been developed by the Oak Ridge National Laboratory and has been successfully used for biological denitrification of nitrate-containing solutions. A $10-\mathrm{cm}-\mathrm{ID}$ column has been operated by $\mathrm{Y}-12$ personnel to test scale-up and operational characteristics of the fluidized bed reactor.

Operating performance of the $10-\mathrm{cm}-1 \mathrm{D}$ column compares well with data from a $5-\mathrm{cm}-1 \mathrm{D}$ column that was operated by ORNL personnel. The operating performance should not be affected by scale up to larger diameters as long as adequate flow distribution can be maintained.

The fluidized bed reactor is characterized by short residence-time requirements labout 2 minutes per meter of height), and by high but variable denitrification rates $(2-35 \mathrm{~g}$ $\mathrm{NO}_{3}{ }^{-}-\mathrm{N} / \mathrm{dm}^{3} / \mathrm{day}$ ).

Operational stability of the reactor has been somewhat of a problem. An adequate biomass control procedure is required for long-term operation. Biomass control in the $10-\mathrm{cm}-1 \mathrm{D}$ reactor was successfully provided by a vibrating screen arrangement; however, unexplained fluctuations in the denitrification performance of the reactor were still noted. Large-scale reactor design must accommodate these fluctuations by sizing the reactor to produce a dischargeable effluent even on the worst operating days.

The fluidized bed reactor is best suited for relatively low-concentration nitrate wastes $\left(<1\right.$ wt $\left.\% \mathrm{NO}_{3}^{-}\right)$, where little or no dilution will be required. Higher-concentration wastes can be processed by appropriate dilution, but the competitive advantage of this type of reactor, compared to a stirred-bed reactor, tends to decrease as the nitrate concentration of the waste strearn increases. Even for extremely concentrated nitrate wastes, the size of the reactor required to treat the waste stream should be smaller when using a fluidized bed reactor than a stirred bed reactor. However, the increased labor time required at the present state of development may outweigh the advantages of the size reduction. 


\section{ACKNOWLEDGEMENTS}

The author wishes to thank C.W. Hancher for his valuable technical advice. J. E. Miner, R. L. Andrews, and G. B. Dinsmore operated the system and performed the chemical analyses. 


\section{REFERENCES}

1. Process Design Manual for Nitrogen Control, USEPA; October 1975.

2. Standard Methods for the Examination of Water and Wastewater, 13th edition; American Public Health Association (1971).

3. Moore, S. F. and Schroeder, E. D.; Water Research 5, pp 445 - 452 (1971).

4. Requa, D. A. and Schroeder, E. D.; JWPCF, 45 (8), pp $1696-1707$ (1973). 


\section{Distribution}

Department of Energy - Oak Ridge

Hickman, H. D.

Large, D. E.

Wing, J. F.

Zachry, D. S., Jr

Department of Energy - Savannah River

Wright, S.

Goudyear Alumic Corporation - Portemouth

Earnhart, M. M.

Emiler, V.S.

Hurt, N. H.

Kaplan, R. I.

Netzer, D.

Lawrence Livermore Laboratory

Nelson, W. E.

Los Alamos Scientific Laboratory

Baker, R. D.

Borduin, L.

Hoyt, H. C.

Keenan, T. K.

Library Services

Monsanto-Mound Laboratory

Bradley, J. E.

Carfango, D. G.

Records Management (2)

National Lead of Ohio

Pennak, A. F.

Oak Ridge Gaseous Diffusion Plant

Jones, G. C

Stief, S. S.

Wilcox, W. J., Jr

Oak Ridge National Laboratory

Ferguson, D. E.

Hancher, C. W.

Oakes, T.W.

Scott, C. D.

Weir, J. R.
Oak Ridge Y-12 Plant

Abee, H. H.

Armstrong, R. C.

Bailey, H. L.

Barkman, J. R.

Bostock, D. J.

Burditt, R. B.

Dodson, W. H./Googin, J. M.

Fraser, R. J.

Jones, F.W.

Jordan, H. G.

Keith, A.

Kite, H. T.

Koger, J.W.

Marrow, G. B.

Mason, D. L.

McLendon, J. D.

Mills, J. M., Jr

Napier, J. M.

Parsons, J.

Phillips, L. R.

Sanders, M.

Strohecker, J. W.

Taylor, P. A. (10)

Tewes, W. E.

White, J. C.

Williams, R. D.

Yaggi,W.J.

Y-12 Central Files (master copy)

$Y-12$ Central Files (route copy)

$Y-12$ Central Files $(Y-12 R C)$

$Y-12$ Central Files (5)

Paducah Gaseous Diffusion Plant

Baker, R. C.

Pulley, N. H.

Rockwell International - Rocky Flats

Wiederecht, D. A.

Zeigler, D.

Savannah River Laboratory

Patterson, $M$.

Union Carbide Corporation - New York

Tinsley, S.W.

In addition, this report is distributed in accordance with Category UC-69. Waste Product Control, as given in the USERDA Standard Distribution Lists for Unclassified Scientific and Technical Reports, TID-4500. 